Olivet Nazarene University

Digital Commons@ Olivet

Faculty Scholarship - Geology

Geology

Fall 2009

\title{
"Insufferably Stupid or Miserably Out of Place": F.A.P. Barnard and His Scientific Instrument Collection in the Antebellum South
}

Stephen Case

Olivet Nazarene University, scase@olivet.edu

Follow this and additional works at: https://digitalcommons.olivet.edu/geol_facp

Part of the Instrumentation Commons, and the United States History Commons

\section{Recommended Citation}

Case, Stephen. "'Insufferably Stupid or Miserably Out of Place': F.A.P. Barnard and His Scientific Instrument Collection in the Antebellum South." Historical Studies in the Natural Science 39.4 (2009): 418-443.

This Article is brought to you for free and open access by the Geology at Digital Commons @ Olivet. It has been accepted for inclusion in Faculty Scholarship - Geology by an authorized administrator of Digital Commons @ Olivet. For more information, please contact

digitalcommons@olivet.edu. 


\title{
"Insufferably Stupid or Miserably Out of Place": F. A. P. Barnard and His Scientific Instrument Collection in the Antebellum South
}

\begin{abstract}
In the 1850s, the American scientist and educator Frederick A. P. Barnard created a collection of scientific apparatus at the University of Mississippi in Oxford, Mississippi, of a size and expense that surpassed any collection in the United States at that time. The collection, which would come to include over three hundred instruments of both American and European manufacture, was the attempt by Barnard, born and educated in the North, to bring Big Science to the South and challenge the dominance of Northern schools in science education. In this respect it failed, and the collection became a forgotten footnote in the history of Southern science. This article examines the importance of the collection in understanding science at U.S. universities before the Civil War and what Barnard referred to as the "scientific atmosphere" of the South. The first section compares the collection to others of the period, highlighting its historical uniqueness and significance. The second section uses Barnard's correspondence to construct a narrative of the collection's assembly, providing insight into the international scientific instrument market of the period as well as the difficulties he faced working in the antebellum South. Finally, an examination of Barnard's perceptions regarding intellectual isolation and the failure of his endeavor highlights differences perceived by scientists of the day concerning the practice of science in the North versus in the South prior to the Civil War.

KEY WORDS: Frederick A. P. Barnard, scientific instruments, French instruments, philosophical apparatus, Lerebours et Secretan, Civil War, University of Mississippi, Joseph Henry
\end{abstract}

*Department of Physical Science, Olivet Nazarene University, One University Avenue, Bourbonnais, IL 6o9I4; scase@olivet.edu.

The following abbreviation is used: FBC, F. A. P. Barnard Collection (MUMoo519), Department of Archives and Special Collections, J. D. Williams Library, University of Mississippi. Throughout this paper, the collection of instruments assembled by Barnard at the University of Mississippi will be called the Barnard Collection. The collection is today referred to as the

Historical Studies in the Natural Sciences, Vol. 39, Number 4, pps. 4I8-443. ISSN 1939-I8II, electronic ISSN 1939-I82X. (C) 2009 by the Regents of the University of California. All rights reserved. Please direct all requests for permission to photocopy or reproduce article content through the University of California Press's Rights and Permissions website, http://www.ucpressjournals.com/reprintinfo. asp. DOI: IO.I525/hsns.2009.39.4.418. 


\section{INTRODUCTION}

The Barnard Observatory, located on the campus of the University of Mississippi in Oxford, Mississippi, is a fitting symbol of Frederick A. P. Barnard's ambiguous legacy in Southern science. Currently occupied by the Center for the Study of Southern Culture, it was constructed over three years beginning in I857 and has served in turns as the Chancellor's residence, a sorority, and (during the Civil War) a hospital for both Union and Confederate troops. An imposing building of red bricks handmade by slave labor, it was modeled on the Imperial Observatory at Pulkovo, Russia. Among its various functions, though, it has never actually served as an observatory. ${ }^{1}$

That it was intended to be so is obvious. It is also obvious that it was intended to be a significant observatory; and indeed, Barnard envisioned it as the crown jewel of Southern science, an attempt to break the North's monopoly of prestige and its dominance in higher science education. Barnard insisted that the telescope purchased for it be the largest manufactured up to that time. All of the equipment would be the finest available, acquired from only the bestknown instrument manufacturers. Oxford, and thus the South, would become renowned as a center for astronomy and the physical sciences.

This never materialized. War came, and the world's largest telescope, contracted through Alvin Clarke and Sons of Cambridge, Massachusetts, never arrived. Oxford was occupied and most of the town burned by Union troops. Barnard, who had such grand designs for science in the South, returned north. The observatory would never house any large telescopes, though courses in physics and astronomy were taught there for a time. What it did house, though, and what for many years gathered dust on its shelves before eventually finding its way to the university's museums, constituted the first step in Barnard's program to bring Big Science to a Southern university: the collection of philosophical apparatus that now bears his name. This collection is among the finest preserved in the United States and at the time was superior to any other in the U.S.

This article outlines Barnard's attempts to establish a significant scientific institution in the South by examining the creation of this collection. The opening

Millington-Barnard Collection in recognition of the fact that many of the instruments in the collection were purchased by the University from John Millington, Barnard's predecessor. However, this paper deals primarily with the purchases made by Barnard in the period $1856-1858$ that compose the large majority of the collection.

I. "Barnard Observatory," The Southern Register (I991): I2-I5. 
section addresses his motivations for assembling the collection and the collection's uniqueness in scope and composition. The following section outlines the process by which Barnard assembled the collection, emphasizing the challenges faced by a scientist working in the geographic isolation of the antebellum South. A third section examines these challenges in terms of intellectual isolation. Finally, I offer limited conclusions that can be drawn from Barnard's experience and the ultimate failure of his enterprise. Throughout, Barnard's unique perspective as a Northerner working in the South provides insight into how a scientist of the time viewed the scientific environment of the South.

\section{THE COLLECTION: "WITHOUT A SUPERIOR ON THE CONTINENT"}

In the rhetoric of the nineteenth century, possession of "philosophical apparatus" (collections of instruments and equipment for demonstrating physical science principles) was symbolic of an institution's standing and prestige in the sciences. As science programs and instruction developed, instrument collections were purchased, constructed, or collected. ${ }^{2}$

Barnard was interested in assembling a philosophical apparatus at the University of Mississippi during this period because he understood what it would mean for Southern science. Though Barnard was a Northerner by birth and had been educated and briefly taught at Yale, he had been working in the South for over ten years (at the University of Alabama) when he was hired as a professor of mathematics and natural philosophy at the University of Mississippi in 1854 . He eventually would become well known as a champion for educational reform, and during his time in the South he developed a passion for bringing to the region the same resources for scientific inquiry and instruction that were available in the North.

He outlined this aim clearly in his Letter to the Honorable, the Board of Trustees of the University of Mississippi, which was his treatise on the importance of science education and a call for its support in the South, written in I858. In the

2. The rapid growth of science programs and instruction at several American colleges and universities in the first half of the nineteenth century up to the outbreak of the Civil War is analyzed extensively in Stanley M. Guralnick, Science and the Ante-Bellum American College (Philadelphia: American Philosophical Society, 1975). One aspect of this growth he emphasizes is money spent on science facilities and equipment, specifically instrument collections. 
letter, he addressed the fact that many Mississippians were sending their children to be educated at schools in the North, despite public sentiment that they should be educated closer to home. One reason for the exodus, he wrote, was the superior equipment and philosophical apparatus found at the institutions: "Our Southern colleges as a class, are in this respect generally deficient. ... Their philosophical and chemical apparatus, their collections illustrative of the mineral, vegetable, and animal kingdoms, - as to these things, the contrast between them and those richly endowed and venerable institutions which so many Southern parents prefer, is so glaring as to thrust itself upon our notice." 3

According to Barnard, the solution was simple. He believed that Mississippi must "throw around our own institutions precisely the same attractions and without any exception all the attractions, which exist elsewhere to draw our youth away." They are leaving, he reiterated, for "colleges supposed to be better provided than ours with the instrumentalities necessary to the satisfactory presentation of subjects of physical science." ${ }^{3}$ Barnard had stated earlier that "Science cannot be properly taught without costly apparatus," and that without such apparatus, colleges "cannot furnish to their students educational advantages equal to those offered by institutions in this respect more favored." 5

Certainly these claims and Barnard's solution cannot be taken solely at face value. As will be seen below, Barnard was in fact writing to tout the costly apparatus that he had by this time purchased for the university. He set out the problem for Southern education so that he could show how the University of Mississippi was a place where these problems were being addressed and could be overcome. Yet despite the self-interest of his rhetoric, the problem of Southern education remained. Barnard was echoing complaints voiced throughout the I840s and I850s by Southern professors, businessmen, politicians, and journalists who bemoaned the loss of Southern students to schools in the North and called for the support of Southern intellectual institutions. ${ }^{6}$

Barnard's response was to make the University of Mississippi a recognized scientific institution by assembling an instrument collection second to none. "The undersigned," Barnard wrote, "would commit an unpardonable oversight, were he not to express his conviction that this University is, to-day, in

3. F. A. P. Barnard, Letter to the Honorable, the Board of Trustees of the University of Mississippi (New York: D. Van Nostrand, I858), 89.

4. Ibid.

5. Ibid., 42.

6. For more on this problem and how it was perceived in the South, see John S. Ezell, "A Southern Education for Southrons," Journal of Southern History 17, no. 3 (1951): 303-27. 
possession of a philosophical and chemical apparatus as a whole without a superior on the continent, and in many of its details unequalled." 7

This claim is echoed in the University of Mississippi Ninth Session Catalogue (probably published in 1856 ):

apparatus has been provided on the most liberal scale; the recent purchases having been extended to embrace whatever could be practically useful in impressing the facts and principles of science upon the mind through the eye; and all the instruments selected have been the best of their class. The University is, in this respect, fairly entitled to claim superiority to most collegiate institutions in the United States. ${ }^{8}$

These claims of superiority must be viewed critically. Barnard's words could easily be construed as a rhetoric of competition, by which proponents of collections would speak either of the inadequacy of a collection in order to raise funds for further purchasing or of the outstanding nature of a collection in order to strengthen perception of an institution to potential students and the public. ${ }^{9}$ It is not enough then to take Barnard at his word alone. The Barnard Collection itself must be examined in terms of its value, "completeness," and method of purchase to confirm or rebut Barnard's assertion of its uniqueness.

Despite the importance of philosophical apparatus during the antebellum period, many institutions had barely enough money to pay for natural philosophy professors, let alone purchase extensive collections of philosophical apparatus. Most universities slowly built their collections over many years as appropriations were obtained or funds collected through special events or from private donors. ${ }^{10}$ Barnard was aware of this financial constraint: "There is not a college in the whole country which can provide itself with books, and instruments, and collections in natural science, and all the other appliances essential to thorough instruction, with no resources beyond the fees paid in by students for their tuition." 11

Institutions that received new instruments only through the occasional donation, or when individual professors were able to make a purchase they

7. Barnard, Letter (ref. 3), 90.

8. University of Mississippi Catalogue for the Ninth Session, 1856-I857 (Memphis: n. p.), 28.

9. David Pantalony, Richard L. Kremer, and Francis J. Manasek, Study, Measure, Experiment: Stories of Scientific Instruments at Dartmouth College (Norwich, VT: Terra Nova Press, 2005), 220-2I.

Io. Guralnick, Science (ref. 2), 70-74.

II. Barnard, Letter (ref. 3), 40. 
considered important or useful as funds became available, had collections that were put together with little overall plan of development. ${ }^{12}$ This piecemeal method of assembly contrasts with that of the Barnard Collection. Barnard purchased the great majority of the instruments nearly all at once, between 1856 and I858. His collection did not depend on fundraising or donations. Barnard's relative freedom in creating the collection allowed him to exercise discretion in determining what would be included. Eugene Hilgard, a close friend of Barnard and colleague at the University of Mississippi, would later write regarding Barnard's construction of the collection that "in all these purchases he was ever careful of the adaption [sic] to instruction and investigation rather than show, and the gift of several collections of miscellaneous curiousities [sic] that would have delighted the heart of the average showman, we declined under that point of view." ${ }^{33}$ The Barnard Collection, unlike many other collections of the period, thus represents a cohesive whole, a single individual's idea of what a complete instrument collection should include, rather than a conglomeration assembled slowly as time and finances allowed.

The average value of a college's instrument collection by 1850 has been estimated at two thousand dollars. If this was indeed the case, it would indicate that the Barnard Collection was unique in terms of value as well. ${ }^{14}$ In I858 Barnard placed the worth of the apparatus for natural philosophy at the University of Mississippi at fifteen thousand dollars. ${ }^{15} \mathrm{~A}$ brief examination of some contemporary instrument collections will help put Barnard's collection in context.

The University of Georgia in Athens, for instance, purchased "several thousand dollars worth of equipment" from the French instrument manufacturer Nicolas Constant Pixii. ${ }^{16}$ In 1824 the University of Charleston attempted to

I2. Guralnick, Science (ref. 2), 70.

I3. Eugene Hilgard, Publications of the Mississippi Historical Society, vol. I2 (Oxford, MS: Mississippi Historical Society, I9I2), I43-44.

I4. Guralnick, Science (ref. 2), 73: "A good approximation is that the average college owned perhaps $\$$ IOO worth of physics apparatus in I $820 \ldots$ and owned at least twenty times that amount in 1850." Guralnick arrives at this estimate from funds spent on philosophical apparatus at Union College, University of Pennsylvania, Wesleyan University, Princeton, and Columbia College during the period $\mathrm{I} 8 \mathrm{IO}-6 \mathrm{I}$.

I5. Ibid., x.

16. Deborah Jean Warner, "French Instruments in the United States," Rittenhouse 8 (1993): I-32, on 2. This value seems rather high, though Warner states that there is an invoice from the purchase in the University of Georgia archives. An article on the history of science at the University of Georgia mentions philosophical apparatus but not this specific and significant purchase. See Thomas G. Dyer, "Science in the Antebellum College: the University of Georgia, I8OI-I860," Science and Medicine in the Old South (Baton Rouge: Louisiana State University Press, 1989), 36-54. 
raise money by donation to purchase a collection of philosophical apparatus. When this failed, the City Council of Charleston provided two thousand dollars "to be expended in the purchase of Philosophical apparatus." 17 Transylvania College in Lexington, Kentucky, had an instrument collection, the total value of which may compare to that of the Barnard Collection, but which was assembled over twenty years and so lacks the Barnard Collection's more coherent, single-purchase nature. ${ }^{18}$

In I833, moreover, the University of Alabama was reported to have "an 'extensive and complete' set of philosophical apparatus 'constructed by European artists, after the most recent and approved models." ${ }^{19}$ Barnard was hired as a natural philosophy professor at the University of Alabama in I8 37 and worked there until joining the University of Mississippi in 1854 . Upon his arrival to Alabama, Barnard was informed, according to his biographer William Chute, that “"natural philosophy' equipment had been purchased abroad by the former Professor John Fielding Wallis in I83I with an authorized appropriation of \$IO,O00." ${ }^{20}$ However, despite the amount spent on this apparatus, Barnard was unsatisfied. He found most of it still in boxes, and when writing to his friend Elias Loomis, complained, "I have no instruments for astronomical observations" and "for illustration in instruction, I have some imperfect apparatus." Barnard's biographer provides a further summary of his evaluation of the collection:

In mechanics the apparatus was complete enough to illustrate mechanical principles with clarity. Nothing was available to teach hydrostatics and hydraulics,

17. Barbara Hughes, Catalog of the Scientific Apparatus at the College of Charleston: 1800-1940 (Charleston, SC: College of Charleston Library Associates, 1980). Whether this entire sum was spent remains unclear; an accounting by the treasurer for the years I8I7 to I832 showed that \$I,446.53 was paid for philosophical apparatus (on p. i). No other significant purchases appear to have been made in the period prior to the Civil War. In a catalog compiled in 1980 of 150 surviving pieces dating from I800 to I940, only thirty instruments date from I800 to I850 (p. 86).

18. Leland A. Brown, Early Philosophical Apparatus at Transylvania College (Lexington, KY: Transylvania College Press, 1959). Around I837 the City of Lexington appropriated \$20,000 "to purchase a Library for the Law Department and to increase the Apparatus and Library of the Medical School" (p. 8). In the summer of 1839, Dr. Robert Peter traveled to Europe on behalf of the college and of this sum purchased $\$ 2,500$ worth of chemical and philosophical apparatus from instrument manufacturers in Paris and London. The next large addition to this collection did not come until I857, when the college purchased Dr. Phillip Fall's collection of for $\$ 4,500$. A complete list of this apparatus is provided in the catalogue, the total value of which Dr. Fall lists as \$6,699 (pp. 9-14).

19. Warner, "French Instruments" (ref. I6), 24.

20. William Chute, Damn Yankee! The First Career of Frederick A. P. Barnard (Port Washington, NY: Kennikat Press, 1978), 89. 
but there were instruments in abundance for explaining the principles of pneumatics; great deficiencies in optics; many electrical trifles but no battery. ... The department was entirely deficient in electromagnetism. So little was there in equipment that Barnard believed he would have to obtain an appropriation. ${ }^{21}$

Despite its monetary value, clearly Barnard did not consider the collection at the University of Alabama complete.

In terms of value, the Barnard Collection appears to have represented the most money spent on philosophical apparatus in a single purchasing event in the United States up to that time. Where did this money come from? As mentioned above, funds for philosophical apparatus usually came through donations or funds appropriated by outside organizations. The funding for the Barnard Collection, in another example of the collection's uniqueness, came from the State of Mississippi. ${ }^{22}$ This appropriation from the state gave Barnard financial freedom to purchase the instrument collection at one time and at his discretion. As he recalled in his memoirs, "In consequence of this [passage of legislation] the trustees authorized the purchases of all the fine apparatus, which is now found in the physical department ... I was permitted to direct these purchases very largely myself." ${ }^{23}$ The instrument collection appears to have been purchased with the first annual appropriation (along with mineral and natural history cabinets, resources for the library, and refurbishments to the laboratories). Barnard would eventually use further payments to construct the observatory.

Though Barnard had the money to make purchases, he did not have the freedom to travel abroad on a purchasing trip to select and assemble the items for the collection. This was certainly frustrating to him at the time, but his

2I. Ibid., 88-89.

22. When legislation was passed authorizing the creation of a state university in Mississippi, a certain portion of land was set aside for its use. Some of this land was eventually sold, and funds from the sale were held in trust for the university by the state. After Barnard's arrival at the University of Mississippi, he looked into the handling of these funds and concluded that the State of Mississippi was responsible to the university for the loss of $\$ 874,324.49$. As a result of Barnard's lobbying, the state legislature passed what became known as the Five Year Law in 1856 . The law called for the State of Mississippi to pay the university $\$ 20,000$ annually over a five-year period. See Allen Cabaniss, The University of Mississippi: Its First Hundred Years (Hattiesburg: University and College Press of Mississippi, I97I). Origins of the Seminary Fund, as the monies from the sale of the property were known, are outlined on pages 4-5. Details of Barnard's work in obtaining the appropriation from the state are given on page 36. See also Chute, Damn Yankee! (ref. 20), I5I.

23. F. A. P Barnard, Publications of the Mississippi Historical Society, vol. 7 (Oxford, MS: Mississippi Historical Society: 1912), II3. 
dependence on correspondence with scientists and instrument dealers abroad provides insights into the structure of the scientific community in the South before the Civil War. That the collection was assembled without a purchasing trip is another aspect of its uniqueness.

The importance of a purchasing trip is obvious, and it was common practice at the time for institutions that found the means to purchase an instrument collection to send a professor, administrator, or agent to Europe to buy the apparatus. ${ }^{24}$ This was true of the University of Alabama, which sent Professor Wallis. The collection at Transylvania College was purchased in 1839 by Dr. Robert Peter, who traveled to Europe, and later additions to the collection had apparently been purchased in Europe as well. ${ }^{25}$ The University of Georgia purchases appear to have been made by Professor Henry R. Jackson either while he was in Paris or soon after his return from Paris. ${ }^{26}$ Such trips allowed individuals to consult with the manufacturers and view available items or demonstrations before making purchases. ${ }^{27}$

Barnard outlined the importance of making a purchasing trip in a letter to Leland Garland years later. Garland, who at this time was Chancellor of Vanderbilt University and who had previously succeeded Barnard as professor of physics and astronomy at the University of Mississippi, had asked for advice on assembling a philosophical apparatus at Vanderbilt. In his response, Barnard wrote, "when large purchases are made, it is desirable that the professor should personally inspect the instruments before delivery; so that if anything is unsatisfactory, it may be made right before packing." 28 Barnard was speaking from the experience of not having been able to do so.

The final trait of uniqueness of the Barnard Collection is its completeness. Using the funds available to him and even though unable to make a purchasing trip abroad, Barnard assembled a collection that he felt confident could rival any other in the United States at that time. Barnard was in a position to make such an evaluation. He had attended and then taught at Yale, where he

24. Guralnick, Science (ref. 2), 72.

25. Brown, Early Philosophical Apparatus (ref. I8), Iо.

26. Warner, "French Instruments" (ref. I6), 2.

27. For more information about purchasing trips of North American scientists abroad, see David Pantalony, "Americans in Europe: The Purchasing Trip of Ira and Charles Young in I853," Bulletin of the Scientific Instrument Society, 76 (2003): 23-27.

28. F. A. P. Barnard to L. C. Garland, I7 Dec I873; reproduced in Robert T. Lagemann, The Garland Collection of Classical Physics Apparatus at Vanderbilt University (Nashville: Vanderbilt University, 1983), 264. 
had presumably worked with that institution's philosophical apparatus and developed an idea of the extent of other collections in the region. He had also worked with a Southern collection at Alabama. Barnard understood what a complete collection would entail and had assembled this at the University of Mississippi. "Although other universities possessed individual pieces not procured by Barnard, none exceeded in magnitude the extensive collection brought together at Oxford." ${ }^{29}$

The Barnard Collection thus represented a unique achievement for the antebellum South and indeed for the entire United States. In regards to its value, it ranked if not superior then certainly equal to any collection assembled in the country by that time. In terms of one-time purchases, no other of such magnitude had ever been made for a U.S. institution. Its composition, being purchased at once by the direction of an individual as opposed to assembled slowly over the life of an institution, made it a cohesive whole and a nearly complete sampling of scientific instruments from that period.

In addition, since Barnard was unable to make a purchasing trip for the collection and appears to have sent no agent in his stead, the Barnard Collection is unique in that it was assembled entirely through correspondence. As a result, the collection does not simply provide insight into the nature of scientific instruments at the time; the process by which Barnard assembled it gives insight into the nature of relationships of North American scientists with one another and with the instrument manufacturers who supplied them. Barnard was working in the relative isolation of the South, far from the industrial and commercial centers of the North, and so the process by which he assembled the collection from abroad provides information about the scientific community of the South in the period before the Civil War. What difficulties did Barnard face working in the South, and how did he overcome them? What conclusions did Barnard ultimately draw from his experiences regarding the scientific endeavor in the South?

\section{CONSTRUCTING THE COLLECTION: "IF I BOUGHT A LOAD OF PIG IRON UNDER THE NAME OF PHILOSOPHICAL APPARATUS"}

The practice of science in the antebellum South did not flourish to anywhere near the degree that it did in the North. Many reasons have been investigated, including the climate of the South, the religious atmosphere of the region, and 
the supposed incompatibility of science and the support of slavery. (Barnard, who is acknowledged as having been one of the leading Southern scientists of the period, owned slaves. ${ }^{30}$ ) Whatever the reasons, it is clear that "judged by almost every measurable criterion ... the Old South lagged markedly behind the Northeast in promoting science," as Ronald L. Numbers and Janet S. Numbers have concluded. ${ }^{31}$

One explanation for this regional disparity in science focuses on the concentration of urban centers in the North and the scarcity of such sites in the South. According to Numbers and Numbers, "antebellum scientists tended to concentrate in urban areas that possessed libraries and a large commercial class." They maintain that this link between science and urbanization provides the most accurate index of scientific activity during the period. ${ }^{32}$

A direct result of this lack of urban centers was the professional isolation experienced by scientists in the South, "away from Charleston and New Orleans Southern scientists languished in intellectual isolation." ${ }^{33}$ Barnard himself wrote that he had "in reality been reduced to idleness and intellectual stagnation by the atmosphere of mental apathy which surrounds a devotee of science here. There is so little attention of mind with mind - there are so few who are intellectually active." ${ }^{34}$ This environment explains the importance that Southern scientists placed on correspondence with their colleagues, primarily those working in the North, in creating a "transregional scientific community, sustained by regular correspondence and occasional visits." ${ }^{35}$

Barnard was one of the most well-known Southern scientists of this period and the only Southerner elected president of the American Association for the Advancement of Science before the Civil War. ${ }^{36}$ His experiences in the South as he attempted to address and reverse this intellectual stagnation reveal how a

30. Ronald L. Numbers and Janet S. Numbers, "Science in the Old South: A Reappraisal," Journal of Southern History 48 (1982): 171-72.

31. Ibid., 164-65. These measurable criteria include birthplace and residencies of American scientists before the Civil War, distribution of membership and leaders of the American Association for the Advancement of Science, and regional distribution of scientific journals and societies.

32. Numbers and Numbers, "Science in the Old South" (ref. 30), I70, 173.

33. Ibid., I75.

34. Ibid., 176. See also Chute, Damn Yankee! (ref. 20), 174.

35. Numbers and Numbers, "Science in the Old South" (ref. 30), 176.

36. Ibid., 172. "The American Association for the Advancement of Science, of which I have been President longer than any of predecessors, (without presiding, since the meetings have been for five and a half years suspended) is about to be reconvoked.” F. A. P. Barnard to E. Hilgard, I9 Feb 1866, FBC, Box K-4, Folder 94-19. 
contemporary scientist participated in this transregional scientific community. The difficulties Barnard faced assembling a superior instrument collection involved communicating by correspondence, overcoming geographical isolation, and dealing with intellectual isolation. These barriers, and what Barnard saw as his ultimate failure to overcome them, illustrate that the practice of science in a region was dependent on more than the idealism and determination of a single individual.

When Barnard arrived at the University of Mississippi in 1854, he inherited a collection of philosophical apparatus that was already unique and relatively extensive. This collection originated from John Millington, Barnard's immediate predecessor at the university. Millington was originally from England, where he had been a member of the Royal Society, and had worked for a time as an instrument manufacturer in Philadelphia and as a professor at the College of William and Mary before being hired as one of the original faculty members of the University of Mississippi in $1848 .{ }^{37}$

In his memoirs, Barnard stated that he believed Millington had been preferred as a candidate for the position of professor of natural philosophy "because of his possession of an excellent collection of apparatus which he proposed to place at the service of the university." Barnard was impressed by the "numerous articles of great historic interest" in the original collection and left "injunctions at the university for their permanent preservation as interesting relics of scientific history." 38 Among these were troughs of a galvanic cell that formed part of the 2,000-plate battery with which Davy performed experiments leading to the discovery of the alkali metals (though its authenticity has recently been called into question). Many of Millington's original pieces still exist in the collection, recognizable by their style of craftsmanship or by Millington's name or initials. Some of the items constructed by Millington include a brachistochrone, a cycloidal pendulum, and a bent-lever balance. This original collection was purchased by the university upon Millington's retirement in 1853 .

Barnard, however, quickly realized that the collection as it stood would not be sufficient for his plans. Extensive additions needed to be made, and by the summer of 1856 he was in New York City, making final arrangements for a purchasing trip abroad. He planned to visit London, where he had been once

37. David G. Sansing, The University of Mississippi: A Sesquicentennial History (Jackson: University Press of Mississippi, 1999), 5I-53.

38. F. A. P. Barnard, Publications of the Mississippi Historical Society, vol. I2 (Oxford, MS: Mississippi Historical Society, I912): 107. 
before in 1838 to place orders for astronomical equipment for the University of Alabama, and Paris. ${ }^{39}$ In July I856, he told his friend Eugene Hilgard, who would eventually become geologist at the University of Mississippi, "All my arrangements were made to start for Europe at this time. I have \$10,000 worth of Phil. Apparatus to purchase." 40

But university politics intervened. The previous president of the University of Mississippi, Augustus Baldwin Longstreet, stepped down unexpectedly, and in the resulting confusion Barnard allowed himself to be considered for the position. His correspondence from the period indicates that he felt ambivalent about the presidency, did not expect to be elected, and had allowed his name to be considered primarily to prevent a rival from obtaining the position without contest. ${ }^{41}$ To his surprise, he was elected and thus forced to cancel his purchasing trip abroad and return to Mississippi.

Though he could not go abroad, Barnard still hoped to use his time in New York to purchase equipment. In this he was frustrated as well. He wrote Hilgard from Albany, "I have been forced to lose, substantially, the entire object of my coming, on account of a [illegible] embarrassment. I have received no written instructions or authority to contract, and I have received no funds. In reply to a telegraphic despatch [sic], I was informed, some days since, that money was coming, but my agent in New York does not yet notify me that it is come; and I am urgently recalled to Mississippi." ${ }^{42}$ A few days later he wrote, "After the lamentable breakdown of all our fine schemes, I return to Oxford with pain. Not one dollar has been sent me. I have trifled away the vacation, and go home again with a very heavy heart." ${ }^{43}$

By 1856 Barnard clearly had the approval to go ahead with construction of the collection, though apparently getting the money to New York for purchases was another matter. However, despite these initial difficulties and the added responsibilities he assumed as university president, the collection seems to have been ordered, delivered, and assembled at the University of Mississippi by I858. Barnard told the Board of Trustees: "At your next assembling you will have the satisfaction of seeing one Southern college, which, in regard to the most important and popular branches of physical science, will present every attraction

39. Gene G. Byrd, "F. A. P. Barnard and Astronomy in the Antebellum South," Alabama Heritage 44 (2000): 17-25.

40. F. A. P. Barnard to E. Hilgard, in Jul I856; reproduced in Chute, Damn Yankee! (ref. 20), I54. 4I. Sansing, University of Mississippi (ref. 37), 74-75.

42. F. A. P. Barnard to E. Hilgard, 24 Aug 1856, FBC, Box K-4, Folder I.

43. F. A. P. Barnard to E. Hilgard, 30 Aug I856, FBC, Box K-4, Folder I. 
to the learner which can be offered by the oldest and best appointed [schools] in the entire country." ${ }^{44}$

The Ninth Session Catalogue, as quoted earlier, makes similar claims as the Letter regarding the completeness of the collection, but its wording gives the indication that much of this apparatus had not yet arrived or was expected to arrive shortly. The writer (presumably Barnard) spoke of instruments that had been purchased in Paris, had been recently constructed, had been ordered, would shortly be received, etc. ${ }^{45}$ Thus it seems likely the writer of the Ninth Session Catalogue was in the process of purchasing the instruments and that this was largely completed at least by the time the Letter was published in 1858 . Since Hilgard mentioned receiving a copy of the catalogue in June 1857 and it was most likely written the year before, it appears that the bulk of the ordering, purchasing, and assembling of the collection took place from I856 to $1858 .{ }^{46}$

Upon his return from New York, Barnard found himself in an interesting position. He had the funds and the designs to purchase and assemble a superior instrument collection, but no longer the freedom to travel abroad. In Mississippi, he was once again working in isolation and forced to rely on correspondence. This meant that the collection was constructed not at Barnard's direction alone but through the resources and connections of others, primarily Joseph Henry and David Van Nostrand. In September 1856, Barnard wrote to Eugene Hilgard's brother Julian to update him on how the work was progressing: "I have had as little time to think of apparatus as of correspondence. I have written to Professor Henry to request that he will take the trouble to order the dia-magnetic apparatus, and a standard barometer and thermometer. Beyond that, I have done nothing." ${ }^{47}$

Joseph Henry was at this time secretary of the Smithsonian Institute in Washington, D.C. He and Barnard wrote to each other often throughout the I86os and presumably the I850s, though no letters dating from this earlier period are

44. Barnard, Letter (ref. 3), 90.

45. University of Mississippi Catalogue (ref. 8), 29-36.

46. E. Hilgard to F. A. P. Barnard, 28 Jun I857, FBC, Box K-4, Folder 2.

47. F. A. P. Barnard to J. Hilgard, 28 Sep 1856, FBC, Box K-4, Folder I. The diamagnetic apparatus mentioned in this passage is also referred to in the Ninth Session Catalogue: "The more recently discovered phenomena of dia-magnetism . . . will be demonstrated by means of a powerful apparatus constructed for the University by Ruhmkorff, of Paris." University of Mississippi Catalogue (ref. 8), 33. This purchase eventually arrived, because it is listed in the I86I inventory of the collection as Ruhmkorffs large diamagnetic electromagnet. According to Warner, "French Instruments" (ref. 16), 17, Henry had obtained the same apparatus from Ruhmkorff in I854. 
known to have survived. ${ }^{48}$ What is known of Barnard's dealings with Henry regarding the purchase of the Barnard Collection is only what can be gleaned from surviving correspondence between Barnard and others. It is likely that Henry, who was in a position better suited for travel and who had an extensive collection of instrument catalogues at the Institute, was largely responsible for the selection of instruments purchased by Barnard. By 1865 Henry obtained copies of the catalogues of the manufacturers Soleil, Breguet, Chevalier, Deleuil, Duboscq, Hartnack, Koenig, Salleron, and Lerebours et Secretan. He also had several of Marloye's catalogues. Having been secretary of the Smithsonian since 1846, he almost certainly had access to a much broader and more recent selection of catalogues for ordering equipment than Barnard would have had at the University of Mississippi. ${ }^{49}$

Despite the connections of colleagues like Henry, the lack of control that arose in allowing others to make purchases for the collection quickly became a major difficulty in assembling the collection by correspondence. By April I857 Barnard was having second thoughts about contracting through Henry. He told Hilgard, "I wish you would definitely ascertain from Henry what he has ordered for me. I have regretted that I troubled him at all on the subject, since I have been left in great uncertainty (as to) what he has done. Especially I desire to know whether he ordered Ruhmkorfs [sic] apparatus for producing the effects of statical [sic] electricity from electro-dynamic arrangements." ${ }^{0}$

Henry is mentioned again in Barnard's correspondence in September 1857. He wrote to Hilgard:

this reminds me of Professor Henry, and leads me to inquire if you could not take some convenient occasion to remind him of what a set of matter of fact men

48. One hundred eighty-three letters between Barnard and Henry, dating from I86I to I878, survive in the Smithsonian's Joseph Henry Papers database. (Query results report provided by Kelly A. Crawford, Smithsonian Institutional History Division, 24 Sep 2007.) There was likely previous correspondence between Henry and Barnard from the 1850 s that burned in an 1865 fire at the Smithsonian which destroyed almost all of the institution's official correspondence. (Kelly A. Crawford, e-mail message to author, I8 Sep 2007.)

49. Warner, "French instruments" (ref. 16), 8, 19.

50. F. A. P. Barnard to E. Hilgard, 30 Apr I857, FBC, Box K-4, Folder 2. The nature of this Ruhmkorff apparatus is uncertain. The description most likely describes an induction coil (Ruhmkorff coil). The I86I inventory of the Barnard Collection lists a Ruhmkorff coil manufactured by Ritchie, indicating that perhaps Henry was unable to obtain one from Ruhmkorff himself. According to Warner, "French Instruments" (ref. I6), I7, Henry ordered a Ruhmkorff coil in the mid-I86os but never received it. Years later, Barnard told Vanderbilt University's Leland Garland that he preferred Ritchie's induction apparatus to Ruhmkorffs. See Lagemann, Garland Collection (ref. 33), 263. 
I have about me. Our executive Committee don't care much about apparatus, and whether we have it or haven't it don't concern them a great deal; but they have a wonderful appetite for vouchers; and if I bought a load of pig iron under the name of philosophical apparatus, they would be perfectly content, if I had the papers to show for it. I do not know but the Professor has sent the bills for foreign purchase to Van Nostrand, but I can get nothing intelligible out of Van Nostrand, least of all these desired "vouchers." 51

Besides highlighting Barnard's frustration with bureaucratic red tape, the passage indicates that Henry had indeed made foreign purchases on Barnard's behalf. However, the line about not much caring whether "we have it or haven't it" seems to indicate that some of the ordered apparatus had still not arrived. Obviously working through correspondence, even with a scientist such as Henry, created significant difficulties.

The Van Nostrand mentioned above was David Van Nostrand, a publisher based in New York City who seems to have been the agent through whom Barnard made his purchases. ${ }^{52}$ Through Van Nostrand, Barnard contracted with at least three companies or individuals: the firm of Lerebours et Secretan, well-known Parisian instrument manufacturers from whom Barnard obtained the majority of the instruments in the collection; E. S. Ritchie, a Boston-based firm Barnard used to construct many instruments of his own design; and an unknown individual named Heinrich Bitter of [sic] Beilefield. The arrangement with Van Nostrand was not always a happy one. In August I857 Barnard wrote to Hilgard, "I am tired of him. I shall have to get a new agent. Not one thing has gone right with him in my business in New York, this year. ${ }^{\text {} 33}$

Though no correspondence between the instrument manufacturer Ritchie and Barnard survives in the University of Mississippi archives, it is certainly possible that Barnard had met Ritchie and seen his equipment during his time in the Northeast, perhaps even on the trip to New York that proved so frustrating. Chief among the special-order apparatus requested from Ritchie was an electrostatic generator referred to in the Ninth Session Catalogue as the main machine in the University's electrical apparatus. The electrical apparatus itself

5I. F. A. P. Barnard to E. Hilgard, 9 Sep I857, FBC, Box K-4, Folder 2.

52. An advertising insert in the back of the Letter that was published by Van Nostrand states: "D. Van Nostrand: Bookseller, Publisher, and Importer . . . would respectfully solicit orders from Public and Private Libraries for the purchase of any Books, Apparatus, or Philosophical Instruments in this country or Europe." Barnard, Letter (ref. 3), end piece.

53. F. A. P. Barnard to E. Hilgard, I3 Aug I857, FBC, Box K-4, Folder 2. 
was said to "be superior to any similar collection in the United States." ${ }^{54}$ This generator, consisting of two glass plates 5.5 feet in diameter, was built according to Barnard's own specifications and was one of his prized instruments. Unfortunately, it never functioned properly due to poor material in the insulating pillars. ${ }^{55}$ The catalogue also mentions an air-pump constructed for the university by Ritchie and built on "the Smithsonian model."

Some of the constraints imposed on Barnard by this purchasing arrangement are illustrated by his purchases from the firm of Lerebours et Secretan. During this period, French instrument manufacturers were acknowledged to have the highest quality instruments available, and they dominated the American market for philosophical apparatus. ${ }^{56}$ Lerebours et Secretan was well known in the I80os, especially for their products in the fields of astronomy, optics, and surveying. Lerebours, before he teamed with Secretan, had already gained acclaim by producing the first French telescopes used in the United States. ${ }^{57}$ The University of Mississippi would prove to be Lerebours et Secretan's first important U.S. customer, but instruments manufactured by the firm could be found at various institutions in the country by the I850s, including the United States Military Academy. ${ }^{58}$ It is not surprising, therefore, that Barnard would have chosen their instruments. The Ninth Session Catalogue often identifies which instruments have been manufactured by Secretan, indicating that at the time the name itself would have lent credence to the quality of the apparatus. ${ }^{59}$

Despite these considerations, it is likely that Barnard's choice of Lerebours et Secretan was influenced more by having to make purchases through correspondence than by the merits of the company alone. For one thing, Barnard made no mention in his surviving correspondence of his reasons for choosing the firm or of its relative merits in comparison to other manufacturers. When Chancellor Leland Garland of Vanderbilt University asked years later for guidance in purchasing a collection for Vanderbilt, in the advice and list of instruments and

54. University of Mississippi Catalogue (ref. 8), 32.

55. W. L. Kennon and Sanford C. Gladden, "Historical Apparatus at the University of Mississippi," American Physics Teacher 6 (1938): I-7.

56. For more information, see Warner, "French Instruments" (ref. I6).

57. For more information regarding Lerebours et Secretan, see Paolo Brenni, "Nineteenth century French Scientific Instrument Makers III: Lerebours et Secretan," Bulletin of the Scientific Instrument Society 40 (1994): 3-6.

58. Other schools included Wesleyan University and St. Louis University. Warner, "French Instruments" (ref. I6), II-I2.

59. University of Mississippi Catalogue (ref. 8), 30-36. The catalogue specifically mentions an air pump, the acoustical apparatus of Marloye, and a large theolodite. 
instrument manufacturers Barnard provided, no mention was made of Lerebours et Secretan. ${ }^{60}$ This does not indicate that Barnard was displeased with their instruments, for though he warned Garland away from certain manufacturers he believed had inferior products, he gave no such warning regarding Lerebours et Secretan. He simply made no mention of the firm, an oddity considering they had furnished the majority of the collection at the University of Mississippi.

The primary factor in Barnard's decision to purchase from Lerebours et Secretan was most likely the company's I853 catalogue, which included over a thousand instruments in a wide variety of fields complete with images and descriptions. ${ }^{61}$ Of the 380 instruments listed in the I86I inventory of the Barnard Collection, 204 are in the 1853 catalogue. (Considering that some of the 380 were already part of the collection at Barnard's arrival, the proportion of instruments purchased by Barnard which were ordered from Lerebours et Secre$\tan$ is actually larger than these numbers represent.) In addition, the organization of instruments in the 186I collection inventory follows the organization of the 1853 catalogue closely; indeed, many of the instruments listed follow the order exactly. Lerebours et Secretan also sold other manufacturers' instruments in their catalogue, including Marloye's acoustical apparatus and Silberman's didactic paintings, which Barnard purchased. (The only known series of Silberman's paintings is in the Barnard Collection. ${ }^{62}$ )

For an individual making purchases through correspondence, a catalogue would have been the easiest vehicle for selection. The correlation between collection and catalogue indicates the influence of this medium on the composition of the collection. Regardless of the relative merits of Lerebours et Secretan as manufacturers, Barnard likely was constrained or at least influenced in his purchasing decisions simply because they had the best catalogue. Indeed, since no copy of this catalogue exists in the University of Mississippi archives, it is possible that Joseph Henry, who did have a copy, made these decisions for Barnard.

6o. F. A. P. Barnard to L. C. Garland, 17 Dec I873; reproduced in Lagemann, Garland Collection (ref. 28), 259-68.

6I. Lerebours et Secretan, Catalogue et prix des instruments d'optique, de physique, de chimie, de mathématiques, d'astronomie et de marine (Paris: Typographie Plon Freres, I853). See also http://www.sil.si.edu/digitalcollections/trade-literature/scientific-instruments/pdf/sili4-51737.pdf (last accessed 3I Aug 2007).

62. For information on Albert Marloye, see Paolo Brenni, "Nineteenth-Century French Scientific Instrument Makers VI: The Triumph of Experimental Acoustics: Albert Marloye (I795-1874) and Rudolph Koenig (I832-I90I)," Bulletin of the Scientific Instrument Society 44 (1995): 13-17. For information on Silbermann's paintings, see Paolo Brenni, "Silbermann's Didactic Paintings in the University of Mississippi Museum," Bulletin of the Scientific Instrument Society 95 (2007): I-7. 
Besides depending on catalogues to assemble his collection, Barnard frequently relied on Hilgard and other friends abroad. The pitfalls of this are illustrated in the case of Mr. Bitter. Though it is unknown for what he was contracted, he was first mentioned in the August 1857 letter above, in which Barnard urged Hilgard to make sure that Van Nostrand had remitted payment to Bitter. ${ }^{63}$ Barnard asked Hilgard again in November to "find out something about Heinrich Bitter." ${ }_{4}$ When Barnard finally did hear from Bitter, he was deeply dissatisfied. He told Hilgard in January 1858 that Bitter "has thrown back, by a whole year, the completion of the arrangements of the lab.... As he will not ship till spring, of course the apparatus will be wholly unavailable for any purpose to us, [in] the present session." ${ }^{65}$ Later in the month he said that "Mr. Bitter has done us a great injury. He has set back the arrangements of our laboratory for work, twelve months; and has entailed upon us endless inconvenience, confusion, brick and mortar." 66

Barnard's interactions with individuals and instrument manufacturers abroad illustrate the challenges an isolated scientist faced working through correspondence. His isolation meant that he lacked the freedom to carefully oversee the creation of the collection. His agent was in New York, his instrument manufacturers in Boston and France, and his closest correspondent (Henry) as far away as Washington, D.C. These distances and the confusion and slow progress that resulted were barriers that would not have been as formidable to a scientist working in one of the urban, mercantile centers of the North. That Barnard was able to assemble such a collection at all, despite these difficulties, is a testament to his determination.

Besides the problems of correspondence, what about simple geographical concerns? How did the geography of the South affect the construction of the collection? At the time of the collection's assembly, Mississippi had been a state for just over forty years. In many ways, Oxford was still a frontier town. The easiest method of transportation would have been over land from ports along the Mississippi. The Natchez Trace was by this time almost fifty years old, and railroads into the interior of the state did not extend to Oxford. Travel to and from the University of Mississippi would have been by coach over dirt or (in rare cases) plank-covered roads. ${ }^{67}$

63. F. A. P. Barnard to E. Hilgard, I3 Aug I857, FBC, Box K-4, Folder 2.

64. F. A. P. Barnard to E. Hilgard, 23 Nov 1857 , ibid.

65. F. A. P. Barnard to E. Hilgard, 3 Jan I858, FBC, Box K-4, Folder 12.

66. F. A. P. Barnard to E. Hilgard, 2I Jan I858, FBC, Box K-4, Folder I4.

67. For accounts of travel throughout Mississippi during this period, see Charles S. Sydnor, A Gentleman of the Old Natchez Region: Benjamin L. C. Wailes (Westport, CT: Negro Universities Press, 1970), 259-85. 
A letter Barnard wrote to Hilgard explaining his plans for an aquarium illustrates the difficulty of transporting materials to the University of Mississippi as well as the importance of professional contacts in acquiring scientific materials (in this case specimens). ${ }^{68} \mathrm{He}$ wrote, "I have been writing to Budd, of New York - and through a friend, to Riddell of New Orleans, about getting an aquarium here." Regarding the necessity of going all the way to New York for living specimens, Barnard explained that it was "[s]imply because I have no correspondence in Savannah or Charleston." He mentioned knowing "gentlemen enough in Mobile" but said they would most likely view the request as absurd. As for the logistics of transporting live specimens from New Orleans or New York, Barnard hoped Hilgard would be willing to accompany the specimens on the trip to ensure that they arrived safely. ${ }^{69}$ Not surprisingly, the university never obtained an aquarium. As with purchasing instruments, obtaining proper specimens depended primarily on contacts in a scientific community. That community was tenuous in the South, and so Barnard nearly always found himself forced to work across great distances.

Added to the difficulties of transportation was the problem of the condition in which the instruments arrived. Hilgard recalled that "[m]any of the instruments imported from Europe had arrived in more of [sic] less damaged condition, and there was no instrument-maker to whom the repairs could be entrusted, nearer than Washington." ${ }^{70}$ Having no one nearby to service or repair them, Barnard was responsible for repairing the equipment on his own with what tools he had available. Though he was reported to have been very skilled in this practice, by now he was also university president, and the effectiveness of the collection was certainly hindered.

\section{INTELLECTUAL ISOLATION: “WHERE I SHALL HAVE A SCIENTIFIC ATMOSPHERE AROUND ME"}

The final and perhaps most significant barrier to Barnard's plans for Big Science in the South was his perception of intellectual isolation. He could attempt to overcome geographic isolation from the scientific community through correspondence and perhaps eventually by traveling abroad; however, his correspondence made

68. Barnard had by this time ordered mineral and conchology cabinets for the university.

69. F. A. P. Barnard to E. Hilgard, in Feb I858, FBC, Box K-4, Folder 2.

70. Charles Sanford Gladden, A History of the Department of Physics and Astronomy at the University of Mississippi I848-1932 (Oxford: University of Mississippi Press, 1994), 45. 
clear that his greatest frustrations came from intellectual isolation, from the feeling that he was working alone to bring about the creation of a scientific institution in a climate of public opinion that was disinclined and disinterested. Barnard wrote of "the temptation to go where I shall have a scientific atmosphere around me." ${ }^{71}$ It was this lack of scientific atmosphere that would eventually cause him, despite what he had created at the University of Mississippi, to give up his hopes for the South and return to what he saw as the more scientifically conducive environment of the North.

Barnard had not come to the University of Mississippi ignorant of the discrepancy between Southern and Northern scientific institutions. He knew the extent of resources available at institutions in the North, and he undertook his program of scientific development in Mississippi specifically to address this discrepancy. However, over time his writings reveal a growing disillusion, until finally he concludes that despite his best efforts to create an institution in the South similar to those in the North, the fundamental problem was not the availability of scientific apparatus but the intellectual environment of the South. Writing from Columbia University, ten years after his time at Oxford, he told Hilgard, "I look back on my life in Mississippi with regrets: In spite of the annoyances which would come from time to time, my life there was a happy life; for I believed (whether rightly or wrongly) that I was making it a useful one. I often find myself ejaculating ' $\mathrm{O}$, if they would only have let well alone!'”72 Clearly, at least in retrospect, Barnard felt that he did not have the freedom to pursue his scientific designs in the South.

What did Barnard perceive in the culture or climate around him that he felt made this desired intellectual independence difficult? Almost as soon as he arrived in Oxford, he spoke of the town as sleepy and lethargic and of the university as young and without traditions. There was an aspect of hopefulness in this, as he saw the university as a sort of blank slate upon which to create the type of institution that he envisioned. ${ }^{73}$ Yet within two years of his arrival, as he began implementing his plans for improvements, he was trying to dissuade colleagues from taking positions in Southern colleges based on his experiences. ${ }^{74}$

There are of course many possible reasons for Barnard's frustrations. It is important to note that difficulties arose at roughly the same time as he began

7I. F. A. P. Barnard to E. Hilgard, 29 May 1859, FBC, Box K-4, Folder 19.

72. F. A. P. Barnard to E. Hilgard, I2 Dec I868, FBC, Box K-4, Folder 62.

73. Chute, Damn Yankee! (ref. 20), I46.

74. F. A. P. Barnard to E. Hilgard, in Nov I856, FBC, Box K-4, Folder I. 
to implement his plans for change and took on his role as president. Some of these frustrations may have been a result of conflicts with individuals or situations unique to the University of Mississippi. These could have been exacerbated by the fact that Barnard was a Yankee and in some respects still an outsider in the South.

At least after the events of the Civil War, there does appear to have been hostility toward Barnard as a Northerner. In an I866 letter, Hilgard (who remained at the University of Mississippi) related an incident in which the new chancellor was congratulated for ridding the university of "Yankee influence." Years later, Barnard wrote that he should not recommend anyone for positions in the South because "my recommendation, I apprehend, would kill in Mississippi the best man that could be started." "76

Yet it must be emphasized that these were attitudes voiced after the war. Before the war and even during the period leading up to it, there seems to have been little hostility directed toward Barnard specifically as a Northerner. Barnard had by this time been living and working in the South over twenty years and was held in general esteem. Students especially rallied behind him, and a student periodical before the war refused to publish an article "on account of its bitter vituperations against northern men" because they felt it was disrespectful to Barnard. ${ }^{77}$ Though Barnard was opposed to secession, his writings were not outspoken in this respect. In fact, a letter he wrote that came to light after the war reflected Southern sympathies, and he was forced to admit that he "had sympathized with the South during the protracted sectional conflict leading up to the war." ${ }^{\prime 8}$ In addition, Barnard presented a series of lectures at the Smithsonian Institute in Washington, D.C. only days after his state of Mississippi seceded from the Union. ${ }^{79}$ If he was strongly opposed to or felt threatened by Southern sentiments, this would have been an ideal time to leave the South. Instead, he returned to the University of Mississippi.

It is certainly difficult to discount the role that the growing national tensions played in Barnard's decision to abandon his scientific endeavors in the South and return North, but his correspondence indicates that this decision, at least consciously, was made independently of political considerations. When in an

75. F. A. P. Barnard to E. Hilgard, 5 Apr 1866, FBC, Box K-4, Folder 2.

76. F. A. P. Barnard to E. Hilgard, 29 Sep 1870, FBC, Box K-4, Folder 64.

77. Sansing, University of Mississippi (ref. 37), 81.

78. Marc Rothenburg, ed., The Joseph Henry Papers, vol. Io (Sagamore Beach, MA: Science History Publications, 2004), 4IIn.

79. Ibid., I9on. 
I859 letter Barnard informed Hilgard that he had given the Board his six months' notice, he said nothing to indicate he felt he was being forced out by anti-Northern sentiment. ${ }^{80}$ Even in his later writings, Barnard did not emphasize personal opposition to him in particular, as a Yankee or otherwise. His reasons for leaving always revolved around frustrations entailed by the lack of scientific community and an atmosphere that would have supported his enterprise.

From Barnard's point of view, there was a distinct contrast between the atmosphere for science in the North and the South. In the North, the scientific community and scientific institutions provided support for the pursuit of science. It was this lack of intellectual support in the South that to Barnard was the greatest hindrance to his work in Mississippi. He said in a letter to Hilgard that "so intolerable was this feeling of uncertainty of the future, that I would rather occupy the humblest station any where where human affairs had any stability than the highest here." ${ }^{\prime 1}$ In the letter where he spoke to Hilgard of the temptation to go where there would be a scientific atmosphere, he also said that there he "shall be free from present cares and from dependence on the uncertain popular breath." Were the Five Year Law (the legislation that provided funds to construct the collection) to be repealed, as Barnard was often certain it would be, he said they would "fall back again into the day of small things and my project of a higher grade of teaching falls to the ground." 82

Yet these are the perspectives of one individual. Were they unique to Barnard and his situation, or can they be set in a broader context of Southern intellectual isolation? In a study of a group of Southern intellectuals who were active in the mid-I8oos, Drew Gilpin Faust explored the relationship among men who were brought together by a common sense of alienation. Their words and experiences provide a powerful reaffirmation of "the desperate loneliness that seemed the lot of the scientist . . in the Old South.” Faust concluded that " $t \mathrm{t}$ ]he neglect of intellect in the South resonated within each of these thinkers as a sense of deep personal loneliness," and he ended his account with the words of Southern writer William Gilmore Simms that "being an intellectual in the South was as rewarding . . . as, 'drawing water in a sieve." ${ }^{83} \mathrm{~A}$ similar perspective is found in medical students returning from schooling in Paris. Back in the South they felt isolated and bored, and complained that they had no access to

8o. F. A. P. Barnard to E. Hilgard, 8 Jun I859, FBC, Box K-4, Folder 20.

8I. F. A. P. Barnard to E. Hilgard, I6 Nov I858, FBC, Box K-4, Folder 2.

82. F. A. P. Barnard to E. Hilgard, 29 May 1859, FBC, Box K-4, Folder 19.

83. Drew Gilpin Faust, A Sacred Circle: The Dilemma of the Intellectual in the Old South, I840-I860 (Philadelphia: University of Pennsylvania Press, I986), x, 2, I8, I48. 
books or opportunities for professional development. ${ }^{84}$ Barnard was not alone in his evaluation of the lack of scientific atmosphere in the South.

Without a strong scientific community, Barnard's efforts in the South depended on the "popular breath," and according to Barnard this support was distinctly lacking. In 1858 he told Hilgard, "I regard the university as a thing too far above the comprehension of the ruling stupidity of the day, to be a success; and therefore I do not expect to stay here beyond another year, or at most two." 85 Earlier that year in another letter, he wrote regarding a scientific pamphlet Hilgard sent him, "I don't believe anybody off the college ground has read it, or could be hired to read it. It makes me feel that I am either insufferably stupid or miserably out of place." ${ }^{\prime 6}$

Add to this Barnard's earlier-mentioned complaint regarding the "idleness and intellectual stagnation" of the South and the presence of "so few who are intellectually active." What is perhaps most significant here is that Barnard wrote these words in 1856 , at the beginning of his assembly of the collection, while near the time of its completion he still felt "insufferably stupid or miserably out of place." Barnard's great scientific endeavor had not changed his perception of the scientific environment. Despite the resources he was able to assemble and the determination by which he created his superior collection, Barnard felt he had failed to bring his vision of science to the people of the South.

\section{CONCLUSION}

The aim of this paper has not been to provide an exhaustive analysis of the differences between the respective scientific communities of the North and South before the Civil War. Rather, it is an attempt to place the experiences of a single scientist working toward a specific goal into the broader context of the period. Frederick Barnard's quest to create a philosophical apparatus at the University of Mississippi superior to any in the nation is the narrative of an individual attempting to address and rectify a trend of the time: that of the North's scientific preeminence over the South. As Barnard wrote to Hilgard at the beginning of his undertaking in 1856 , "I have been governed . . by the principle

84. John Harley Warner, "Remembering Paris: Memory and the American Disciples of French Medicine in the Nineteenth Century," Bulletin of the History of Medicine 65 (I99I): 30I-25.

85. F. A. P. Barnard to E. Hilgard, I6 Nov I858, FBC, Box K-4, Folder 2.

86. F. A. P. Barnard to E. Hilgard, II Jun 1858 , ibid. 
that it is better to do a thing once for all well, than to be always doing. ... We have got the money—so why not?" 87

He had the money and the determination, but what he lacked was an environment that he felt could sustain his cause. He would not find it until he returned North. Assuming the presidency of Columbia University in October I864, Barnard continued his scientific work, wrote extensively on educational reform, and interacted closely with Joseph Henry and other prominent scientific figures of the period. In 1867 he traveled to France as a representative to the Paris Exhibition. ${ }^{88}$ For years he maintained his correspondence with Hilgard, who eventually became Mississippi state geologist and remained for some time at the University of Mississippi. Besides occasional wistful comments regarding Barnard's endeavors in the South, much of their correspondence includes discussions of the instruments Barnard had left behind in Mississippi and detailed instructions for their usage. ${ }^{89}$

While Barnard's collection never brought about the results he had hoped for, it did influence the next extensive collection of scientific apparatus at a Southern institution. When Barnard left the University of Mississippi, he was replaced by Landon Cabell Garland. As professor of physics and astronomy, Garland had charge of the instrument collection Barnard had created and as a result, though he had never studied in the North or traveled abroad, during his eight years of teaching at the university he was exposed to a collection of instruments of the finest quality and extent. When Garland left Mississippi and was named chancellor of the newly organized Vanderbilt University, he thus had firsthand experience and an example of the type of instrument collection he wished to assemble at Vanderbilt.

The Vanderbilt Collection, which Garland began in 1875 and which would eventually amount to over three hundred personally selected items, eventually surpassed the Barnard Collection in expense. (Garland had \$24,000 at his disposal for physics and astronomy equipment. He is said to have arrived at this estimate by marking all desired items in apparatus catalogues and totaling the price, a method that perhaps echoes Barnard's method of selection.) Garland

87. F. A. P. Barnard to E. Hilgard, 30 Apr I856, FBC, Box K-4, Folder I.

88. Rothenburg, Henry Papers (ref. 79), 267, 356, 419. See also F. A. P. Barnard, Reports of the United States Commissioners to the Paris Universal Exposition, vol. 3 (Washington, DC: Government Printing Office, I876).

89. For example, in a letter of 26 Oct 1865 (FBC, Box K-4, Folder 2), Barnard gave Hilgard a very detailed description of the operation of an optical device called a diasporometer. He concluded by discussing the differences between Dubosq's improvements and Roehon's original. 
appealed to Barnard for guidance in assembling the collection. Barnard's response, which included the advice that Garland should himself travel to Europe to make the purchases, contained lists of suggested pieces of equipment and very specific advice regarding instrument manufacturers and who was best for what type of apparatus: "As to static electricity, magnetoelectricity, pneumatics, hydrostatics, etc., you cannot do better than to go to Ritchie. I would rather have Ritchie's induction apparatus than Rumkorff s. . . For acoustics, you should go of course to Koenig. For general optics, to Duboscq." As noted earlier, no mention is made of Lerebours et Secretan..$^{90}$

It would be almost twenty years, however, before Barnard's endeavor in the South was repeated. Though the Barnard Collection remained largely intact, science after the Civil War was "at a low ebb in the South." No additional purchases of philosophical apparatus would be made at the University of Mississippi until 1875 and never again on the scale of Barnard's. ${ }^{91}$ The collection, and the telescope-less observatory that housed it, quickly became relics, a monument to a failed effort to bring scientific atmosphere to the South.

\section{ACKNOWLEDGMENTS}

The author would like to thank Theresa Levitt of the Department of History at the University of Mississippi, under whose guidance this research was conducted. Thanks also to Thomas Marshall, chair of the Department of Physics at the University of Mississippi, for encouragement and access to relevant documents. Finally, thanks to Albert Sperath of the University Museums for access to the collection and to the referees of Historical Studies in the Natural Sciences for their helpful comments and suggestions.

90. Lagemann, Garland Collection (ref. 28), 263-64.

91. Kennon, "Historical Apparatus" (ref. 55), 7. 